\title{
Pisanie jako dramatyzacja
}

Doświadczenie pisania jest doświadczeniem dramatycznym. Pisząc, buduję scenę, rozstawiam na niej imaginowane postacie, każę im mówić swoje kwestie, po czym często odbieram im imiona, by tak - w pozorze jednogłosu - zastygały, przechodząc $w$ stan gotowości do poddania się aktowi lektury.

„Pisanie jest zaczynaniem” - mówił Jacques Derrida, a przed nim Michaił Bachtin uświadomił dramatyczność jako właściwość każdej wypowiedzi. W powtórzeniu ,ja” jest też „nie ja”. W powieleniu obecności uobecnia się brak, w powtórzeniu nieobecności odsłania się istnienie.

Jak zatem dziś wejść w tekst, jeśli nie przeciąć gdzieś własnego pisania, nie podjąć go raz jeszcze w nawiązaniu, powtórzeniu, kontynuacji. Pisze się okręgami, spiralnie, wciąż na nowo wracając po znanych torach, ale zataczających coraz szersze kręgi. Któż byłby dziś tak naiwny albo nieskromny, by wierzyć, że wymyśla coś nowego, nie idąc po czyichś śladach. Często tropy innych przekształcamy we własne, czasem także powtarzamy własne po to, by dodawać, zmieniać, komplikować lub upraszczać. Czasem w końcu zostawiamy na drodze własne ślady ze świadomością, że podejmą je inni. Pisanie jest myśleniem, utrwalane krystalizuje się $\mathrm{w}$ procesie technicznego zapisu, potwierdza się lub zaprzecza sobie. Pisanie jest rozmową, dialogiem myśli z upływającym czasem, dyskusją niewyrażalnego zlowionego w papier, tusz i literę, spotkaniem wewnętrznej inwencji $\mathrm{z}$ uzewnętrznionym aktem elokucji. Pisanie, choćby na pozór tak zdawać się mogło, nie jest tylko linearnym nanizywaniem słów na nić konstrukcji zdaniowej i umieszczaniem w porządku składni. Pisanie jest rozgrywającym się dramatem stałego wchodzenia tekstu w siebie, jest rytmem nawrotów, inkrustacji i natchnien.

Wracają w myślach pozostawione wątki, niedopowiedziane pomysły, niespełnione analizy. Wiele $\mathrm{z}$ dawnych refleksji odżywa znów, by powtórzone w innych porządkach, odsłonić kolejne sensy, by pojawiając się w nowych układach otworzyć dalsze pola interpretacji. Właściwie chciałoby się czasem różne teksty rozrzucić i poukładać od nowa. Podjęte pomysły - kiedyś zarzucone - domagają się rozwinięcia, zmodyfikowania oczekują refleksje dawne.

Dramaturgia pisania powstaje zarówno $\mathrm{w}$ niezwerbalizowanych myślach i niejasnych przeczuciach, jak i pomysłach wyrażonych w mowie. Pisze się wraz z narastaniem słów i presją wewnętrznych obrazów, pisze się najpierw w sobie. 
Jak zacząć pisanie? Wszystkie początki miały już swój czas świetności, a niektóre zdążyły nawet uzyskać ironiczny pogłos będący jedynie ich farsowym wariantem. Któż dziś odważy się napisać pierwsze zdanie na wzór „Markiza wyszła o piątej” lub w stylu Butorowskiej drugiej osoby „Idziesz, rozumiesz, że...”. Któż w końcu rozpoczyna pisanie od autotematycznej refleksji na temat niemożliwego zaczynania $w$ poczuciu, że tworzy coś nowego? Starożytni byli uczciwsi, ustanowione retoryczne toposy nie wymagały oryginalności, były umownymi znakami początku czy końca tekstu.

Przez całe życie pisze się jedną książkę, choć czasem się wydaje, że jest inna, nowa, tak naprawdę ma początek w poprzedniej, z której wyrasta, ale idzie jednak dalej swoją własną drogą. Refleksje teoretyczne zostają wpisane $\mathrm{w}$ interpretacje tekstów literackich. Chodzi przecież stale o to, by te dwa języki nie pozostawały sobie obce, by nie mogły być znowu rozcięte i odsunięte od siebie. Toteż analizy utworów prowokują refleksje ogólnej, literackiej natury, a fragmenty przywoływanych teorii stają się planem rozwoju wypowiedzi interpretacyjnych. Staram się, by tak ustanowić scenę pisma, by głosy teoretyków przeplatały się z głosami pisarzy. Wyobraźnia podsuwa także dalej idące chęci uchwycenia potencjalnych dyskusji, które się nigdy nie odbyły. Niemożliwe do zaistnienia w ludzkim czasie i przestrzeni rozmowy, nie wykluczają przecież takich dialogów tekstów. Co powiedziałby Witkacy Derridzie na temat teorii marginesów po swoich artystycznych i dramatycznych glosach zbudowanych podczas lektury?

Pisanie jest ustawicznym redagowaniem, stałą retoryczną korekcją, niemym palimpsestem skrywającym głębokie warstwy znaczenia, nieustanną korektą niewyrażonego myślenia i napisanego tekstu. Dlatego przypomina układanie pisma, którego życie wyznacza rytm zmian, poprawek i niepewności lektury.

Pisanie jest wynikiem refleksji analitycznych, może nie do końca wyczerpujących, a na pewno niezamkniętych, refleksem ustawicznego zaczynania, powrotów i powtórzeń, fragmentaryczności, otwierania ciągów myśli, analiz, hipotez. Można by powiedzieć za Rolandem Barthes'em, że pisząc pragnie się widzieć czynność pisania jako przyjemność nie tylko wynikającą z czytania literatury, lecz jako radość z pozyskiwania artystycznych tekstów (utworów literackich, wypowiedzi pisarzy, interpretacji estetyków, krytyków sztuki, literaturoznawców, które odsłaniają nieoczekiwanie cechy sprzyjające opisowi i ujęciu przystające do wizji i współtworzące koncepcję dramatycznego dyskursu w sztuce i refleksji o niej). 
Pisanie jest podobne działaniu teatralnemu, jest stałym rozgrywaniem sceny, wchodzeniem $\mathrm{w}$ dialog z partnerami, w momencie kiedy zaczyna się stabilizować, już się kruszy i rozpada, gdy ogarnia je czas. Nie ma w pisaniu postaci bez aktora, który mu nada charakter i sens, czasem ukryje pod maską, kiedy indziej wysunie na przód sceny.

Gdy znikają narracyjne ramy, otwierają się nowe dramatyczne przestrzenie.

Anna Krajewska 